\title{
Correlation of Vitamin D levels with feto-maternal outcome
}

\author{
Nidhi Chauhan $^{1 *}$, Nikita Pahuja ${ }^{1}$, Vinita Kalra ${ }^{2}$ \\ ${ }^{1}$ Department of Obstetrics and Gynecology, Himalayan Institute of Medical Sciences, SRHU, Dehradun, Uttarakhand, \\ India \\ ${ }^{2}$ Department of Biochemistry, Himalayan Institute of Medical Sciences, SRHU, Dehradun, Uttarakhand, India
}

Received: 15 December 2017

Accepted: 19 December 2017

*Correspondence:

Dr. Nidhi Chauhan,

E-mail: manumanan@rediffmail.com

Copyright: () the author(s), publisher and licensee Medip Academy. This is an open-access article distributed under the terms of the Creative Commons Attribution Non-Commercial License, which permits unrestricted non-commercial use, distribution, and reproduction in any medium, provided the original work is properly cited.

\begin{abstract}
Background: Vitamin D deficiency in adult females may increase risk of pre-eclampsia, gestational diabetes, bacterial vaginosis. Various malpresentation, cephalo-pelvic disproportion and difficult deliveries increases the risk of caesarean section. It may also increase the risk of fetal hypovitaminosis D, neonatal rickets and tetany, lower respiratory tract infections, low birth weight, the largest cause of infant mortality in India. This study was under taken to study the impact of vitamin D deficiency on feto-maternal outcome.

Methods: The study was conducted in the Department of Obstetrics and Gynaecology, Himalayan Institute of Medical Sciences (HIMS), Swami Ram Nagar, Dehradun, over a period of 12 months. Sample size was 100 pregnant females attending antenatal clinic.

Results: Out of 100 subjects, pre-eclampsia was seen in 15, among which 5 (23.80\%) had deficient, 9 (13.04\%) had insufficient and $1(10 \%)$ had sufficient vitamin D levels. Eclampsia was seen in 3 subjects, out of which $1(4.76 \%)$ had deficient, $2(2.89 \%)$ had insufficient vitamin D status. IUGR was seen in 8 subjects, out of which $4(19.04 \%)$ had deficient vitamin D levels, $4(5.79 \%)$ had insufficient vitamin D status. Neither of the two had sufficient vitamin D status. Deficient vitamin D status with birth weight $\leq 2.5 \mathrm{~kg}$ was seen in 9 (42.85\%) subjects and $12(57.14 \%)$ subjects with $>2.5 \mathrm{~kg}$ Insufficient Vitamin D status was seen in $22(31.88 \%)$ subjects with birth weight $\leq 2.5 \mathrm{~kg}$ and 48 $(69.56 \%)$ with birth weight $>2.5 \mathrm{~kg}$.

Conclusions: Prevalence of vitamin D deficiency and insufficiency was noted in this region and its association with pre-eclampsia $(23.80 \%, 13.04 \%$ and $10 \%$ in deficient, insufficient and sufficient group respectively) was seen. Higher incidence of LSCS was also present among the deficient and the insufficient group.
\end{abstract}

Keywords: Correlation, Feto-maternal outcome

\section{INTRODUCTION}

Vitamin D deficiency in adult females may increase risk of pre-eclampsia, gestational diabetes, bacterial vaginosis. $^{1}$ Various malpresentation, cephalo-pelvic disproportion and difficult deliveries increases the risk of caesarean section. It may also increase the risk of fetal hypovitaminosis $\mathrm{D}$, neonatal rickets and tetany, lower respiratory tract infections, low birth weight, the largest cause of infant mortality in India. ${ }^{2}$

Though reported incidence of vitamin D deficiency in India is very high but certain subsets of pregnant women are at higher risk i.e. obesity, darker pigmentation or expected date of delivery (EDD) in winter/spring which may even require higher-dose supplementation. ${ }^{3}$ 
In a population that already has a high prevalence of vitamin $\mathrm{D}$ deficiency and poor dietary calcium intake, the problem is likely to worsen during pregnancy because of the active transplacental transport of calcium to developing foetus. In the light of existing evidence, public health intervention to reduce the prevalence of hypovitaminosis $\mathrm{D}$ in pregnant women is imminently desirable. Therefore, present study was undertaken to study the impact of Vitamin D deficiency on fetomaternal outcome.

\section{METHODS}

The study was conducted in the Department of Obstetrics and Gynaecology, Himalayan Institute of Medical Sciences (HIMS), Swami Ram Nagar, Dehradun, over a period of 12 months after obtaining written informed consent and ethical clearance certificate from the institute.

It was an observational, cross sectional study. Considering the prevalence of vitamin D deficiency among women in India to be $80 \%$ (57) with an allowable error of $10 \%$ sample size calculated was $100(100 \%$ enumeration during the study period) convenient sampling. Sample size was 100 pregnant females attending antenatal clinic.

Study was carried out on all pregnant subjects presenting to the Obstetrics and Gynaecology department. Subjects were selected from antenatal clinic OPD, HIMS, Dehradun.

\section{Inclusion criteria}

- All pregnant women between 12 weeks to 24 weeks

- Less than 30 years of age.

\section{Exclusion criteria}

- All high-risk pregnancies including pre-eclampsia, diabetes mellitus, anemia, twin pregnancy, HIV positive, HBsAg positive, jaundice, heart disease, history of seizures

- Gravida 5 or more

- On category C, D and X drugs

- Bad obstetric history.

\section{Study tool}

Structured study instruments (questionnaires/formats/subject proformas and investigations) were developed used to generate data for the study.

\section{Study protocol}

All the women included in the study were followed up by regular antenatal check-up. High vaginal swab was collected at initially and repeated as applicable to rule out bacterial vaginosis. Any abnormalities in the mother or fetus were recorded. All women were delivered in the hospital. Intranatal complications, route of delivery and fetal outcome were recorded. Neonate were followed for 7 days for any complications.

\section{Data management and statistical analysis}

Interpretation and analysis of obtained results were carried out by using SPSS (Statistical package for Social Sciences) version 17 and statistical analysis of the qualitative data was done using the chi square test for intergroup comparisons.

\section{RESULTS}

Out of 100 subjects, pre-eclampsia was seen in 15 , among which $5(23.80 \%)$ had deficient, 9 (13.04\%) had insufficient and $1(10 \%)$ had sufficient vitamin D levels. Eclampsia was seen in 3 subjects, out of which 1 (4.76\%) had deficient, $2(2.89 \%)$ had insufficient vitamin D status. IUGR was seen in 8 subjects, out of which 4 (19.04\%) had deficient vitamin D levels, 4 (5.79\%) had insufficient vitamin D status. Neither of the two had sufficient vitamin D status. Bacterial vaginosis was seen in 7 subjects, out of which $3(14.28 \%)$ had deficient, 3 $(4.34 \%)$ had insufficient and $1(10 \%)$ had sufficient vitamin D status. Gestational diabetes was seen in 5 subjects, of which $2(9.52 \%)$ had deficient, $2(2.89 \%)$ had insufficient and $1(10 \%)$ had sufficient vitamin D status. PROM was seen in $4(19.04 \%)$ subjects who had deficient vitamin D status. None of the subjects had Insufficient and sufficient vitamin D status (Table 1).

Table 1: Distribution of subjects according to Vitamin D status and its association with various complications.

\begin{tabular}{|llll|} 
Complications & $\begin{array}{l}\text { Deficiency } \\
(\mathrm{n}=21)\end{array}$ & $\begin{array}{l}\text { Insufficiency } \\
(\mathrm{n}=69)\end{array}$ & $\begin{array}{l}\text { Sufficiency } \\
(\mathrm{n}=10)\end{array}$ \\
\hline Pre-eclampsia & $5(23.80 \%)$ & $9(13.04 \%)$ & $1(10 \%)$ \\
\hline Eclampsia & $1(4.76)$ & $2(2.89 \%)$ & 0 \\
\hline $\begin{array}{l}\text { IUGR } \\
\text { Bacterial } \\
\text { vaginosis }\end{array}$ & $4(19.04 \%)$ & $4(5.79 \%)$ & 0 \\
\hline $\begin{array}{l}\text { Gestational } \\
\text { diabetes }\end{array}$ & $2(14.28 \%)$ & $3(4.34 \%)$ & $1(10 \%)$ \\
\hline PROM & $4(19.52 \%)$ & $2(2.89 \%)$ & $1(10 \%)$ \\
\hline
\end{tabular}

Out of 100 subjects, deficient vitamin D status was seen in $5(23.80 \%)$ subjects who delivered pre-term and 16 (76.19) subjects who delivered at term. Insufficient vitamin D status was seen in $6(8.69 \%)$ subjects who delivered preterm and $63(91.30 \%)$ subjects who delivered at term. Sufficient vitamin D status was seen in $2(20 \%)$ subjects who delivered pre-term and $8(80 \%)$ subjects who delivered at term. $\mathrm{P}$ value was $0.154(.0 .05)$ which was statistically not significant (Table 2). 12 $(57.14 \%)$ subjects had vaginal and 2 (9.52\%) had 
instrumental delivery with deficient vitamin D status. LSCS was done in $7(33.33 \%)$ subjects with deficient status. Vaginal delivery was seen in $52(75.36 \%)$, instrumental delivery was seen in $3(4.34 \%)$ and 14 $(20.28 \%)$ subjects had LSCS with insufficient vitamin D status.4 (40\%) had vaginal delivery, instrumental delivery was seen in $1(10 \%)$ subjects and $5(50 \%)$ subjects had LSCS with sufficient vitamin D status (Table 3 ).

Table 2: Distribution of subjects according to vitamin D status and gestational age.

\begin{tabular}{|llll}
$\begin{array}{l}\text { Gestational } \\
\text { age }\end{array}$ & $\begin{array}{l}\text { Deficiency } \\
(\mathrm{n}=21)\end{array}$ & $\begin{array}{l}\text { Insufficiency } \\
(\mathrm{n}=69)\end{array}$ & $\begin{array}{l}\text { Sufficiency } \\
(\mathrm{n}=10)\end{array}$ \\
\hline Preterm & $5(23.80 \%)$ & $6(8.69 \%)$ & $2(20 \%)$ \\
\hline Term & $16(76.19 \%)$ & $63(91.30 \%)$ & $8(80 \%)$ \\
\hline
\end{tabular}

Table 3: Distribution of subjects according to vitamin $D$ status and mode of delivery.

\begin{tabular}{|llll|}
\hline $\begin{array}{l}\text { Mode of } \\
\text { delivery }\end{array}$ & $\begin{array}{l}\text { Deficiency } \\
(\mathrm{n}=21)\end{array}$ & $\begin{array}{l}\text { Insufficiency } \\
(\mathrm{n}=69)\end{array}$ & $\begin{array}{l}\text { Sufficiency } \\
(\mathrm{n}=10)\end{array}$ \\
\hline $\begin{array}{l}\text { Vaginal } \\
\text { delivery }\end{array}$ & $12(57.14 \%)$ & $52(75.36 \%)$ & $4(40 \%)$ \\
\hline Instrumental & $3(9.52 \%)$ & $5(4.34 \%)$ & $1(10 \%)$ \\
\hline LSCS & $7(33.33 \%)$ & $14(20.28 \%)$ & $5(50 \%)$ \\
\hline
\end{tabular}

Live birth was seen in $21(100 \%)$ deficient subjects and none had still birth/ IUD. Live birth was seen in 67 $(97.10 \%)$ subjects who had insufficient vitamin D status and $2(2.89 \%)$ subjects had IUD. $10(100 \%)$ live birth with sufficient vitamin D status (Table 4).

Table 4: Distribution of subjects according to vitamin D status and fetal outcome.

\begin{tabular}{|llll|}
\hline $\begin{array}{l}\text { Fetal } \\
\text { outcome }\end{array}$ & $\begin{array}{l}\text { Deficiency } \\
(\mathbf{n}=21)\end{array}$ & $\begin{array}{l}\text { Insufficiency } \\
(\mathbf{n}=69)\end{array}$ & $\begin{array}{l}\text { Sufficiency } \\
(\mathbf{n}=10)\end{array}$ \\
\hline Live & $21(100 \%)$ & $67(97.10 \%)$ & $10(100 \%)$ \\
\hline $\begin{array}{l}\text { Still } \\
\text { birth/IUD }\end{array}$ & 0 & $2(2.89 \%)$ & 0 \\
\hline
\end{tabular}

Deficient vitamin D status with birth weight $\leq 2.5 \mathrm{~kg}$ was seen in $9(42.85 \%)$ subjects and $12(57.14 \%)$ subjects with $>2.5 \mathrm{~kg}$ Insufficient Vitamin D status was seen in 22 $(31.88 \%)$ subjects with birth weight $\leq 2.5 \mathrm{~kg}$ and 48 $(69.56 \%)$ with birth weight $>2.5 \mathrm{~kg}$.

Sufficient vitamin D status was seen in $3(30 \%)$ subjects with birth weight $\leq 2.5 \mathrm{~kg}$ and $7(70 \%)$ subjects with birth weight $>2.5 \mathrm{~kg}$. P value was $0.603(>0.05)$ which was statistically not significant (Table 5).

Table 5: Distribution of subjects according to vitamin $D$ status and birth weight.

\begin{tabular}{|llll}
$\begin{array}{l}\text { Birth } \\
\text { weight }\end{array}$ & $\begin{array}{l}\text { Deficiency } \\
(\mathbf{n}=21)\end{array}$ & $\begin{array}{l}\text { Insufficiency } \\
(\mathbf{n}=69)\end{array}$ & $\begin{array}{l}\text { Sufficiency } \\
(\mathbf{n}=10)\end{array}$ \\
\hline$\leq 2.5 \mathrm{gm}$ & $9(42.85 \%)$ & $22(31.88 \%)$ & $3(30 \%)$ \\
\hline$>2.5 \mathrm{gm}$ & $12(57.14 \%)$ & $29(69.56 \%)$ & $7(70 \%)$ \\
\hline
\end{tabular}

\section{DISCUSSION}

In the current study, Vitamin D deficiency was seen in $23.80 \%$, insufficiency in $13.04 \%$ and even $10 \%$ subjects with sufficient vitamin D status developed pre-eclampsia.

Similar to the present study, Wei SQ et al found association of vitamin D deficiency and insufficiency with higher incidence of pre-eclampsia. ${ }^{4}$ Bodnar LM et al also found vitamin D deficiency as an independent predictor of preeclampsia and low vitamin D status in the neonate. ${ }^{5}$ While Powe et al found no association between maternal $25(\mathrm{OH}) \mathrm{D}$ deficiency and the risk of preeclampsia. ${ }^{6}$ However more studies are required for correlation.

IUGR was seen in $19.04 \%$ who had deficient and $5.79 \%$ with insufficient vitamin D status. None of the subjects had sufficient vitamin D levels.

According to the present study Booke et al, who studied British mothers of Asian descent, found a greater incidence of small-for-gestational-age infants born to mothers who received placebo than in mothers who received vitamin D supplements during pregnancy. ${ }^{7}$

Bacterial vaginosis was present in $14.28 \%$ having deficient and $4.34 \%$ having insufficient vitamin D status.

In contrast, Barclay $\mathrm{L}$ in a study determined the prevalence of bacterial vaginosis which was approximately $57 \%$ in women with deficient serum $25(\mathrm{OH}) \mathrm{D}$ concentration, and it was $23 \%$ in women with sufficient serum $25(\mathrm{OH}) \mathrm{D}$ concentration. ${ }^{8}$

In the present study, gestational diabetes mellitus was present in $9.52 \%$ having deficient and $2.89 \%$ having insufficient vitamin D status.

Similarly, in accordance to our study Makgoba $\mathrm{M}$ et al and Baker et al stated there were no statistically significant differences in maternal mean 25(OH)D levels between those who subsequently developed GDM. ${ }^{9,10}$ While Zhang et al found plasma $25(\mathrm{OH}) \mathrm{D}$ at 16 weeks gestation to be significantly lower in women who subsequently developed GDM. ${ }^{11}$

In the current study, deficient vitamin D status was seen in $23.80 \%$ subjects who delivered preterm and $76.19 \%$ subjects who delivered at term. Insufficient vitamin D status was seen in $8.69 \%$ subjects who delivered preterm and $91.30 \%$ subjects who delivered at term. $\mathrm{p}$ value was 0.154 (>0.05) which was statistically not significant.

While Shibata $\mathrm{M}$ et al and Hollis et al in comparison with term controls, women with a high risk of preterm labor displayed significantly lower serum $25(\mathrm{OH}) \mathrm{D}$ levels. ${ }^{12,13}$

In the current study, $57.14 \%$ subjects had vaginal and $9.52 \%$ had instrumental delivery with deficient vitamin D 
status and LSCS was done in $33.33 \%$ subjects. Vaginal delivery was seen in $75.36 \%$, instrumental delivery in $4.34 \%$ and $20.28 \%$ subjects had LSCS with insufficient vitamin D status.

Merewood A et al and Papandreou et al also reported higher cesarean delivery rates for women with serum 25(OH)D levels. ${ }^{14,15}$ Live birth was $100 \%$ in deficient subjects and $97.10 \%$ subjects who had insufficient vitamin D status. $2.89 \%$ subjects had IUD with insufficient vitamin D status. No correlation exists.

In the present study, there was no significant difference in the birth weight of the new-born of subjects with deficient and insufficient vitamin D status. $\mathrm{p}$ value was 0.603(>0.05) which not statistically significant.

Similarly, Ana $M$ et al found no correlation between $25(\mathrm{OH}) \mathrm{D}$ levels and neonatal gestational age or weight. ${ }^{16}$

In contrast to the present study, Bodnar et al reported that the relationship among Caucasian women between maternal serum $25(\mathrm{OH}) \mathrm{D}$ levels before the $22 \mathrm{nd}$ week of pregnancy and the risk of an SGA birth between 24 and $32 \mathrm{ng} / \mathrm{mL} 25(\mathrm{OH}) \mathrm{D}$ levels. ${ }^{17}$

\section{CONCLUSION}

Prevalence of vitamin D deficiency and insufficiency was noted in this region and its association with pre-eclampsia $(23.80 \%, 13.04 \%$ and $10 \%$ in deficient, insufficient and sufficient group respectively) was seen.

Higher incidence of LSCS was also present among the deficient and the insufficient group. So, more studies are required, however prophylactic administration of vitamin $\mathrm{D}$ along with calcium as is the practice mandatory is recommended.

We do not recommend more supplement over and above it even though encouragement of outdoor activities, and exposure to adequate sun light is recommended and highly desirable.

\section{ACKNOWLEDGMENTS}

Authors would like to acknowledge Mr. Deepak Kumar for his technical help.

Funding: No funding sources

Conflict of interest: None declared

Ethical approval: The study was approved by the Institutional Ethics Committee

\section{REFERENCES}

1. Delvin EE, Salle BL, Glorieux FH, Adeleine P, David LS. Vitamin D supplementation during pregnancy: effect on neonatal calcium homeostasis. J Pediatr. 1986;109:328-34.

2. Purvis RJ, Barrie WJ, MacKay GS. Enamel hypoplasia of the teeth associated with neonatal tetany: a manifestation of maternal vitamin D deficiency. Lancet. 1973;2:811.

3. Bodnar LM, Simhan HN, Powers RW, Frank MP, Cooperstein E, Roberts JM. High prevalence of vitamin D insufficiency in black and white pregnant women residing in the northern United States and their neonates. J Nutr. 2007;137:447-52.

4. Wei SQ, Audibert F, Hidiroglou N, Sarafin K, Julien $\mathrm{P}, \mathrm{Wu} \mathrm{Y}$, et al. Longitudinal vitamin $\mathrm{D}$ status in pregnancy and the risk of pre-eclampsia. BJOG. 2012;119:832-9.

5. Bodnar LM, Catov JM, Simhan HN, Holick MF, Powers RW, Roberts JM. Maternal vitamin D deficiency increases the risk of preeclampsia. J Clin Endocrinol Metab. 2007;92:3,517-22.

6. Powe CE, Seely EW, Rana S, Bhan I, Ecker J, Karumanchi SA, et al. First trimester vitamin D, vitamin $\mathrm{D}$ binding protein, and subsequent preeclampsia. Hypertension. 2010;56:758-63.

7. Brooke OG, Brown IRF, Bone CDM. Vitamin D supplements in pregnant Asian women: effects on calcium status and fetal growth. $\mathrm{Br}$ Med $\mathrm{J}$. 1980;1:751-4.

8. Barclay L. Vitamin D deficiency linked to bacterial vaginosis. J Nutr. 2009;139:1157-61.

9. Makgoba M, Nelson SM, Savvidou M, Messow CM, Nicolaides K, Sattar N. First-trimester circulating 25hydroxyvitamin D levels and development of gestational diabetes mellitus. Diabetes Care. 2011;34:1091-3.

10. Baker AM, Haeri S, Camargo CA Jr, Stuebe AM, Boggess KA. First trimester maternal vitamin D status and risk for gestational diabetes mellitus: a nested case-control study. 2012;28(2):164-8.

11. Zhang C, Qiu C, Hu FB. Maternal plasma 25hydroxyvitamin $\mathrm{D}$ concentrations and the risk for gestational diabetes mellitus. Plos One. 2008;3:e3753.

12. Shibata M, Suzuki A, Sekiya T, Sekiguchi S, Asano S, Udagawa Y, et al. High prevalence of hypovitaminosis D in pregnant Japanese women with threatened premature delivery. J Bone Miner Metab. 2011;29(5):615-20.

13. Hollis BW, Johnson D, Hulsey TC, Ebeling M, Wagner CL. Vitamin D supplementation during pregnancy: Double blind, randomized clinical trial of safety and effectiveness. J Bone Miner Res. 2011;26(10):2341-57.

14. Merewood A, Mehta SD, Chen TC, Bauchner H, Holick MF. Association between vitamin D deficiency and primary cesarean section. J Clin Endocrinol Metab. 2009;94(3):940-5.

15. Pehlivan I, Hatun S, Aydoğan M, Babaoğlu K, Türker G, Gökalp AS. Maternal serum Vitamin D levels in the third trimester of pregnancy. Turk J Med Sci. 2002;32:237-41. 
16. Fernández-Alonso AM, Dionis-Sánchez EC, Chedraui P, González-Salmerón MD. The Spanish Vitamin D and Women's Health Research Group first-trimester maternal serum 25-hydroxyvitamin D3 status and pregnancy outcome. Int J Gynecol Obstet. 2012;116(1):6-9.

17. Bodnar LM, Catov JM, Zmuda JM, Cooper ME, Parrott MS, Roberts JM, et al. Maternal serum 25- hydroxyvitamin D concentrations are associated with small-forgestational age births in white women. J Nutr. 2010;140(5):999-1006.

Cite this article as: Chauhan N, Pahuja N, Kalra V. Correlation of Vitamin D levels with feto-maternal outcome. Int J Reprod Contracept Obstet Gynecol 2018;7:137-41. 